\title{
QUANTUM JOURNALISM: \\ PRINCIPLES OF METHODOLOGICAL INSTITUTIONALIZATION
}

\section{Citation:}

\section{Oleksandr Kholod,}

Doctor of Science in Philology,

Head of the Department of Journalism,

E-mail:akholod@ukr.net,

https://orcid.org/0000-0002-6851-0176

ResearcherID: $A A D-5598-2019$

Vasil Stefanik Carpathian National

University,

Shevchenko st., 57, Ivano-Frankivsk, Ukraine, 76000.
Kholod, O. (2021). Quantum Journalism: Principles of Methodological Institutionalization. Social Communications: Theory and Practice, Vol. 12(1),

22-37.

DOI: $10.51423 / 2524-0471-2021-12-1-1$

Retrieved from

https://new.comteka.com.ua/index.php/journal/articl e/view/4

(C) Kholod O., 2021

(c)) EY

Attribution 4.0 International (CC BY 4.0)

\section{ANNOTATION}

The aim of the study was to formulate the basic principles of methodological formulation of quantum journalism concept (Latin - «quantum journalism», abbreviated - QJ with the pronunciation [k'udzei]; in Ukrainian - «kudzhei»).

Methodology. In the group of general methods, the method of monistic idealism was chosen, this presupposes the primacy of the spirit. In line with monistic idealism, we rely on the concept of quantum infinity. Among the empirical methods the axiomatic method and the hypotheticaldeductive method were used. The first, axiomatic method, allowed to put forward positions that did not require proof. On their basis, the theses that formed the axiomatic theory of the functioning of quantum journalism derived. The hypothetical-deductive method became the basis for making a hypothesis and further proving its validity by deduction.

Conclusions. According to the results of the research, the basic principles of methodological systemization of quantum journalism were formulated. When studying the theoretical foundations of quantum journalism, it is necessary to use the potential of quantum theory (mainly its Copenhagen interpretation). The study of practical activities within quantum journalism carried out based on the position that the trends that recorded in the field of the micro world have their transformations in the macro world. Quantum journalism is considered a social institution, which is a theoretical and practical form of social activity of specialists in social communications and based on ideas that are hypothetically formulated in mathematics and quantum mechanics. In quantum journalism, the unit of analysis (as well as the unit of measurement) is a synergetic-convergent and cross-transmedia unity, the elements of which alone (in isolation) cannot represent the total action, on the one hand, and which alone do not represent the characteristics of the set, on the other.

Key words: quantum journalism, methodological institutionalization, quantum mechanics, institutionalization. 


\title{
КВАНТОВА ЖУРНАЛІСТИКА: ПРИНЦИПИ МЕТОДОЛОГІЧНОЇ ІНСТИТУАЛІЗАЦІЇ
}

\author{
Олександр Холод, \\ доктор філологічних наук, \\ завідувач кафедри журналістики \\ Прикарпатського національного університету імені Василя Стефаника \\ (м. Івано-Франківськ, Україна)
}

\section{Вступ}

Проблема дослідження полягає у відсутності уявлення про квантову журналістику як фахову діяльність людини. Невідомими $є$ й шляхи поєднання теоретичного смислу поняття «квант» як фізичного явища 3 поняттям «журналістика» як форми практичної діяльності. Нині відсутні знання про об'єкт і предмет квантової журналістики, методологію й методики вивчення ії процесів. Ми не знаємо про те, якою може бути одиниця(-ці) аналізу й одиниця (-ці) вимірювання згаданих процесів. Отже, аналізована нами проблема як знання про відсутність знань об'єкта дослідження (Научное знание. Проблема, 2020) є суцільним незнанням. Воно потребує свого вирішення, що ми розглядаємо як нагальну необхідність подальшого пізнання діапазону взаємодії квантової теорії з теорією журналістики.

Спираючись на висловлене, формулюємо мету свого дослідження: сформулювати основні принципи методологічної інституалізації квантової журналістики.

Об'єктом дослідження вважаємо методологічну інституалізацію квантової журналістики, предметом - пї основні принципи.

\section{Методи й методики дослідження}

Матеріалістичні методи є методами тієї наукової картини світу, від якої ми відійшли, що дало нам можливість прийняти протилежний бік бачення світобудови. Незважаючи на декларовану трансформацію, ми переконані, що серед методів матеріалізму є продуктивні й корисні для здійснення нами поставленої мети - методологічної інституалізації квантової журналістики. Ідеалістичні методи також не мають повного діапазону (якщо такий можливий) свого ресурсу для обгрунтування згаданої інституалізації в межах квантової журналістики. Вважаємо за доцільне зазначити, що для нашого дослідження придатними можуть бути не стільки різко диференційовані матеріалістичні чи ідеалістичні методи, скільки ті методи, якими послуговуються представники й матеріалізму, й ідеалізму, i, можливо, інших (дуалістичних) наук, які не відносять до жодної з філософських платформ. Пояснимо доцільність й об'єктивність такого підходу до визначення діапазону методів свого дослідження тим, що всесвітній досвід застосування методологій різних наукових шкіл свідчить про однобокість результатів, що отримуються таким чином. Ми підтримуємо методологічну позицію професора В.В. Крутова (Крутов, 2014; Крутов, 2018; Крутов, 2020-1; Крутов, 2020-2), який стверджує, що ми не маємо права очікувати на той час, коли антагоністичні наукові кола зійдуться у своїх методологіях і «запропонують» світові валідні й верифіковані методи для розв'язання нагальних проблем людства практичними методами. Із давніх часів у науковому й ненауковому світі існують різні шляхи (методи) досягнення, наприклад, здорового способу життя, оздоровлення духу, формування суспільної думки, налаштування економічних засад існування суспільства, підтримки безпечного рівня життя людей тощо. Під час розв'язання згаданих проблем людство не запитує про те, чи 
матеріалісти, чи ідеалісти або дуалісти запропонували певний успішний метод. Важливим у такому випадку є позитивний результат. Саме тому ми не пристаємо лише, наприклад, до матеріалістичних або ідеалістичних методів, метафізичних чи методів містиків. Прагнемо взяти від людського методологічного досвіду лише практично корисні шляхи вивчення явищ i процесів світобудови, наслідуючи при цьому єдину мету покращення реальності, іiі прогресивну трансформацію.

Щоб нас не звинуватили в еклектизмі, або в тому, що ми методологічно чинимо неправильно, послуговуючись методами антагоністичних наукових напрямків, детально обгрунтуємо можливість застосування в нашому дослідженні кожного методу.

Оскільки в сучасній науці для вивчення процесів і явищ, що пов’язані з духовною складовою людини, продуктивно паралельно застосовуються різні методи (і матеріалістичні, й ідеалістичні), ми сформуємо оригінальну методологію (систему методів) подальшого пошуку й у декількох словах запропонуємо характеристику кожного з тих, які доцільно, на наш погляд, залучити.

Оскільки варто розрізняти три групи методів (загальні методи процесів пізнання, методи теоретичного дослідження й емпіричні методи), із кожної групи оберемо ті, що будемо вважати валідними"

У групі загальних методів звертаємося до методу моністичного ідеалізму (Холод, 2018; Холод, 2020-1; Холод, 2020-2), який передбачає первинність духу. У руслі моністичного ідеалізму ми спираємося на концепиію квантової безмежності (від лат. conceptu «концепція»; лат. quántum - «квантовий» і лат. «infinitum» - безмежність; далі - скорочено ККБ, або лат. CQI), яку запропонували раніше (Холод, 2020-1).

Із групи валідних теоретичних методів обрали аналіз як розчленування цілого предмета (квантової журналістики) на його складові (об’єкт, предмети, методи). Нам у подальшому дослідженні корисним буде метод синтезу, який дозволить з'єднати раніше виділені частини предмета дослідження (об'єкт, предмети й методи) у єдине ціле - квантову журналістику, але вже без другорядних факторів (складників), що буде зумовлено застосуванням методу абстрагування як відволікання від низки властивостей і відносин складників квантової журналістики й зосередження на властивостях і відносинах, що цікавлять нас. Ми не зможемо обійти метод узагальнення, оскільки його потенціал дозволить установити загальні властивості й ознаки квантової журналістики.

Серед емпіричних методів найбільш валідними вважаємо, по-перше, аксіоматичний метод i, по-друге, гіпотетико-дедуктивний метод. Перший, аксіоматичний метод, дозволить нам висувати положення, що не вимагатимуть доведення. На їхній базі зможемо виводити тези, що будуть утворювати аксіоматичну теорію про функціонування квантової журналістики. Гіпотетико-дедуктивний метод стане основою для висування гіпотези й подальшого доведення її правильності або хибності шляхом дедукції.

Спираючись на викладені методологічні основи подальшого дослідження, можемо сформулювати гіпотезу. Передбачаємо, що квантова журналістика має принципи методологічної інституалізації.

\section{Результати й обговорення}

Із метою уточнення понять і термінів, що їх означають, на початку свого дослідження звернемося до визначень ключових слів, якими будемо оперувати в подальших розмислах.

\footnotetext{
${ }^{1}$ Валідність - «міра адекватності дослідницьких інструментів (методик проведення експериментів, процедур вимірювання, тестів тощо) тим завданням, для вирішення яких вони створені». (див.: Валідність. Енциклопедія сучасної України. Дата звернення 15.01.2021 http://esu.com.ua/search_articles.php?id=32984).
} 
Перш за все звернемося до термінів «квант», «журналістика», «квантова журналістика», «принципи методологічної інституалізації».

Термін «квант» походить від латинського слова «quantum», яке перекладається як «скільки». Словники зазначають, що під квантом у фізиці мають на увазі таку частку, яка $\epsilon$ неподільною. Також вважається, що квант - це загальна назва порції енергії (Квант, 2020). «В основі поняття лежить уявлення квантової механіки про те, що деякі фізичні величини можуть приймати тільки певні значення (кажуть, що фізична величина квантується). У деяких важливих окремих випадках ця величина або крок її зміни можуть бути тільки цілими кратними деякого фундаментального значення - й останне називають квантом» (Квант, 2020). Візьмемо до уваги наведене визначення й, ураховуючи його смисл, сформулюємо власне, орієнтуючись на те, що наше дослідження стосується гуманітарної галузі життєдіяльності людини - журналістики. Разом із цим варто уточнити значення терміна «журналістика». Під ним маємо таку соціально орієнтовану фахову діяльність, яка спрямована на пошук і відбір суспільно важливої інформації, іiї підготовку до аналізу й трансляції для масового сприйняття та подальшу орієнтацію на вплив журналістської продукції на аудиторію. Звідси термін «квантова журналістика» пропонуємо тлумачити як здійснення порційного (від «порція») впливу на аудиторію, при цьому слід ураховувати, що та інформація, яка транслюється журналістом, є неподільною на дрібніші «порції» і $\epsilon$ частиною більш значимої інформації. Таким чином, квантова журналістика за своєю суттю, на перший погляд, є тією самою звичайною журналістикою, але за умови, що одиницею аналізу в ній слід вважати не лише слово, синтагму, речення, абзац, період чи текст, які є традиційними одиницями в лінгвістичній орієнтації журналістики. Не слід вважати одиницею аналізу у квантовій журналістиці лише суспільно чи політично важливу подію в житті індивідів, соціальних груп, спільнот чи соціальних інститутів або політичних суб’єктів, що притаманно відповідно соціологічній і політологічній орієнтаціям дослідників журналістики. Неправильним буде вважати, що одиницею аналізу у квантовій журналістиці є психологічний вплив і як результат - зміна моделей поведінки особистості чи психологічної групи. Одиницею аналізу у квантовій журналістиці пропонуємо вважати три специфічні риси, що спираються на три основні постулати (принципи, закони, категорії) квантової механіки. Ідеться про принщии невизначеності В. Гейзенберга, принции доповнюваності H. Бора, поняття «суперпозииї̈» $i$ «сnостерігач». Звертаючи увагу на те, що багатьом дослідникам-гуманітаріям важко розібратися в термінах, що активно застосовуються в межах квантової механіки, далі ми здійснюємо порівняльний аналіз класичних визначень згаданих принципів і понять із тими, які ми пропонуємо застосовувати у квантовій журналістиці (див. табл. 1, 2 і 3 далі).

У табл. 1 (див. Додаток 1) ми подали дефініцію принципу невизначеності В. Гейзенберга, яка сформульована таким чином: «Принцип невизначеності стверджує, що існують фундаментальні перешкоди для точного одночасного вимірювання двох або більшої кількості параметрів системи 3 довільною похибкою. У прикладі з вільною частинкою це означає, що принципово неможливо знайти таку хвильову функцію, яка була б власним станом одночасно й імпульсу, і координати. Із цього й випливає, що координата та імпульс не можуть бути одночасно визначені з довільною похибкою. Із підвищенням точності вимірювання координати максимальна точність вимірювання імпульсу зменшується й навпаки. Параметри, для яких таке твердження справедливе, мають назву канонічно пов'язаних» (Квантова механіка, 2020; Гейзенберг, 1989). Аналіз наведеного визначення дозволив нам сформулювати авторське бачення застосування його ознак і критеріїв, що фіксуються в мікросвіті, щодо тих, які притаманні сучасній журналістиці. Таким чином, принцип невизначеності В. Гейзенберга передбачає, що в журналістів (виробників медійного 
продукту) і в аудиторії різні критерії ідентифікації інформації, іiі відбору, підготовки, трансляції та вимірювання впливу на моделі поведінки. За принципом невизначеності у квантовій журналістиці $\epsilon$ істинним твердження «Чим більше прагнення до точності вимірювання якості журналістського продукту, тим менший ступінь вірогідності адекватного відбиття змісту такого продукту й навпаки». Наслідуючи термінологію квантової механіки, критерії такої взаємозалежності в журналістиці назвемо спряженими критеріями. Детальний порівняльний аналіз тенденцій двох визначень принципу невизначеності В. Гейзенберга (у квантовій механіці й журналістиці) дозволив нам стверджувати повну подібність (100\%) між ними.

Наступне поняття квантової механіки, до тенденцій якого ми звертаємося, називається принцип доповнюваності Н. Бора. Суть принципу сформульована в декількох джерелах, які ми цитуємо далі: «...кожна фізична величина разом зі своєю канонічно спряженою утворює пару комплементарних величин, при цьому в будь-якому стані квантової системи певне значення може мати лише одна 3 них, або ж вони обидві не мають певного значення» (Принцип_доповнюваності, 2021). Автори інших джерел пропонують таке визначення: «принцип доповнюваності намагається пояснити, яким чином одна й та ж частинка може мати хвильові та корпускулярні властивості, як це випливає з корпускулярно-хвильового дуалізму Луї де Бройля. Якщо в класичній фізиці для опису вільної частинки використовуються дві змінні: координата та імпульс, то у квантовій механіці існують два підходи: в одному змінною є координата, а в іншому - імпульс. Відповідно, у першому імпульс може мати точне значення, у другому точне значення може мати координата» (Принцип_доповнюваності, 2021). Є також й інші визначення (Кравченко, 2002; Давидов, 2012).

Тепер звернемося до тих тенденцій принципу доповнюваності, які фіксуються, на наш погляд, також у квантовій журналістиці. Принцип доповнюваності тут тлумачиться нами як неможливість здійснення аналізу циркулювання журналістського продукту в медіапросторі лише з боку виробника такого продукту, але так само неможливо здійснити об'єктивний аналіз лише з боку аудиторії. У кожної сторони $є$ лише їй притаманні критерії аналізу. Жоден із них не відбиває об'єктивної картини процесу й повинен розглядатися як комплементарний один щодо одного. Разом із тим один і той самий журналістський продукт може мати як оцінку його виробників, так й оцінку об'єкта, на який його спрямовано (аудиторія).

Наступними поняттями квантової механіки, якими ми послуговуємося під час уведення в науковий обіг нових понять і термінів, що їх позначатимуть, є поняття «спостерігач» $\mathrm{i}$ «суперпозиція». Розгляд обох понять маємо робити в одному абзаці, оскільки як у квантовій механіці, так і у квантовій журналістиці вони не можуть функціонувати в обігові окремо. Вони взаємопов'язані. Оскільки предмет нашого обговорення є складним не лише для гуманітаріїв, а й для фізиків, звернемося до точних формулювань двох згаданих понять і термінів. Отже, «у квантовій механіці, «спостереження» $є$ синонімом вимірювання, «спостерігач» - синонімом вимірювальної апаратури, а спостережуване - із тим, що можна виміряти. Одним з основних понять квантової механіки є сформульована ще в 1924 році в спільній роботі Бора, Крамерса й Слейтера інтерпретація хвильової функції $\psi$ як хвилі ймовірності, а не реальної хвилі, як припускав Луї де Бройль» (Квантова механіка, 2020). Інше джерело повідомляє про те, що «згідно 3 принципом суперпозиції, якщо квантова система може перебувати в станах $\psi_{1}$ і $\psi_{2}$, то вона може знаходитися також і в стані а $\psi_{1}+$ $\mathrm{b} \psi_{2}$, де a тa b - будь-які комплексні числа, які задовольняють умову нормування $|\mathrm{a}|^{2}+|\mathrm{b}|^{2}=1$ » (Принцип суперпозиції (квантова механіка), 2021). Автори ілюструють свою думку: «...Розглянемо, наприклад, частку, яка в одному стані має імпульс р 1 (позначимо його кет- 
вектором $\left.\left|\mathrm{p}_{1}\right\rangle\right)$, а в іншому імпульс $\mathrm{p}_{2}$ (позначимо його $\left.\left|\mathrm{p}_{2}\right\rangle\right)$. Згідно із принципом суперпозиції дана частка може також перебувати, наприклад, у стані $\left|\mathrm{p}_{1}\right\rangle+\left|\mathrm{p}_{2}\right\rangle$. Яким у такому випадку буде імпульс частинки? Висновок квантової механіки полягає в тому, що імпульс у такому стані невизначений. Якщо його виміряти, то можна 3 однаковою ймовірністю отримати або значення $\mathrm{p}_{1}$, або ж значення $\mathrm{p}_{2}$. ...Для квантової системи значення фізичної змінної може бути невизначеним» (Принцип суперпозиції (квантова механіка), 2021).

Звертаючись до подібності тенденцій, які ми фіксуємо в аналізованих поняттях «суперпозиція» і «спостерігач» у межах квантової механіки й у межах журналістики, розтлумачимо їхню сутність у квантовій журналістиці. У ній також, як і у квантовій механіці, поняття «суперпозиція» пов'язане з поняттям «спостерігач» і застосовується до інформації як порції енергії (кванту) у декількох випадках:

1) прояв кванту інформації можливий лише тоді, коли є спостерігач (ним може бути як сам журналіст, так й аудиторія, і засоби вимірювання впливу мас-медіа на аудиторію); без спостерігача інформація не може колапсуватися (схлопуватися), або ідентифікуватися 3 множини можливостей перебігу подій;

2) коли журналіст, трансформуючи інформацію згідно 3 поставленою метою, може впливати на енергетичний (квантовий) потенціал інформації та формувати з неї потрібний засіб маніпуляції (у формі мутації, інмутації чи абмутації) (Холод, 2012); у такому випадку слід вважати, що одна й та сама інформація має можливість колапсуватися (схлопуватися), інтерпретуватися різними журналістами по-різному: іншими словами, саме журналіст колапсує певний енергетичний (квантовий) «заряд» інформації; причому від рівня майстерності, типу темпераменту, типу характеру, інтелектуального фону й розумових здібностей журналіста залежить ступінь такої квантової зарядженості, як і ступінь іiі подальшої реалізації в суспільстві;

3) коли здійснюється вимірювання впливу квантової інформації на аудиторію, непередбачуваною є реакція аудиторії на вміст інформації: реакція може бути як позитивна (домовимося називати таку тенденцію «мутаційне колапсування інформації»), так негативна (назвемо «інмутаційне колапсування інформації»), а іноді абмутаційна реакція, коли може фіксуватися відсутність будь-яких змін у колективній поведінці аудиторії (назвемо таку тенденцію «абмутаційне колапсування інформації».

Пропонуємо декілька пояснень до загального бачення методики складання трьох таблиць (див. табл. 1-3 у Додатках).

\section{Таблиця 1.}

Порівняльний аналіз класичних визначень принципів і понять квантової механіки та їхніх тлумачень у межах квантової журналістики (принцип невизначеності В. Гейзенберга)

\begin{tabular}{|c|c|c|c|}
\hline \multirow[b]{2}{*}{$\begin{array}{l}\text { Принципи й поняття } \\
\text { квантової } \\
\underline{\text { механіки }}\end{array}$} & \multicolumn{2}{|c|}{$\begin{array}{l}\text { Ступінь } \\
\text { кореляції } \\
\text { (у \%): }\end{array}$} & \multirow[b]{2}{*}{$\begin{array}{c}\text { Принципи й поняття } \\
\text { квантової жсурналістики }\end{array}$} \\
\hline & 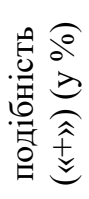 & 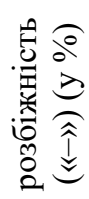 & \\
\hline \multicolumn{4}{|c|}{ Принцип невизначеності В. Гейзенберга } \\
\hline $\begin{array}{l}\text { «Принцип невизначеності стверджує, що існують } \\
\text { фундаментальні перешкоди для точного } \\
\text { одночасного вимірювання двох або більшої }\end{array}$ & + & - & $\begin{array}{l}\text { Принцип невизначеності передбачає, що в } \\
\text { журналістів (виробників медійного } \\
\text { продукту) і в аудиторії різні критерії }\end{array}$ \\
\hline
\end{tabular}


кількості параметрів системи $з$ довільною похибкою. У прикладі з вільною частинкою це означає, що принципово неможливо знайти таку хвильову функцію, яка була б власним станом одночасно й імпульсу, і координати. Із цього й випливає, що координата та імпульс не можуть бути одночасно визначені з довільною похибкою. Із підвищенням точності вимірювання координати максимальна точність вимірювання імпульсу зменшуються й навпаки. Параметри, для яких таке твердження справедливе, мають назву канонічно спряжених» (Квантова механіка, 2020; Гейзенберг, 1989).

Підсумок

\begin{tabular}{|c|c|c|}
\hline & & $\begin{array}{l}\text { ідентифікації інформації, ії відбору, } \\
\text { підготовки, трансляції та вимірювання } \\
\text { впливу на моделі поведінки. За } \\
\text { принципом невизначеності у квантовій } \\
\text { журналістиці є істинним твердження «Чим } \\
\text { більше прагнення до точності } \\
\text { вимірювання якості журналістського } \\
\text { продукту, тим менший ступінь } \\
\text { вірогідності адекватного відбиття } \\
\text { змісту такого продукту й навпаки». } \\
\text { Критерії такої взаємозалежності назвемо } \\
\text { спряженими критеріями. }\end{array}$ \\
\hline 100 & 0 & \\
\hline
\end{tabular}

По-перше, аналізовані нами принципи й поняття квантової механіки стосуються процесів і явищ, що зафіксовано в механіці як розділі фундаментальної природничої науки фізики, саме тому, на думку прихильників класичної та квантової фізики (Гейзенберг, Шрёдингер, Дирак, 1934; Вакарчук, 2012; Ландау, Лифшиц, 2008; Schrödinger, 1935), не можуть бути інтерпольовані на гуманітарні науки, до яких традиційно відносяться журналістика й медієвістика.

По-друге, необхідно зазначити, що ми не шукали штучних паралелей чи метафор, які б споріднювали квантову механіку й журналістику, а, навпаки, фіксували в журналістиці досить давно відомі принципи й закономірності, які до теперішнього часу не мали однозначної назви.

Таблиця 2.

Порівняльний аналіз класичних визначень принципів і понять квантової механіки та їхніх тлумачень у межах квантової журналістики (принцип доповнюваності Н. Бора)

\begin{tabular}{|c|c|c|c|}
\hline \multirow{2}{*}{$\begin{array}{l}\text { Принципи й поняття } \\
\frac{\text { квантової }}{\underline{\text { механіки }}}\end{array}$} & \multicolumn{2}{|c|}{$\begin{array}{c}\text { Ступінь } \\
\text { кореляції } \\
(\mathrm{y} \%): \\
\end{array}$} & \multirow{2}{*}{$\begin{array}{c}\text { Принципи й поняття } \\
\text { квантової әсурналістики }\end{array}$} \\
\hline & 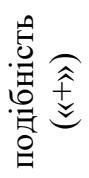 & 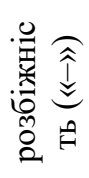 & \\
\hline \multicolumn{4}{|c|}{ Принцип доповнюваності Н. Бора } \\
\hline $\begin{array}{l}\text { «...Кожна фізична величина разом зі своєю } \\
\text { канонічно спряженою утворює пару } \\
\text { комплементарних величин, при цьому в будь- } \\
\text { якому стані квантової системи певне значення } \\
\text { може мати лише одна з них, або ж вони обидві } \\
\text { не мають певного значення» } \\
\text { (Принцип_доповнюваності, 2021). «Принцип } \\
\text { доповнюваності намагається пояснити, яким } \\
\text { чином одна й та ж частинка може мати хвильові } \\
\text { та корпускулярні властивості, як це випливає з } \\
\text { корпускулярно-хвильового дуалізму Луї де } \\
\text { Бройля. Якщо в класичній фізиці для опису }\end{array}$ & + & - & $\begin{array}{l}\text { Принцип доповнюваності у квантовій } \\
\text { журналістиці тлумачиться як } \\
\text { неможливість здійснення } \\
\text { аналізу циркулювання журналістського } \\
\text { продукту в медіапросторі } \\
\text { лише з боку виробника такого продукту. } \\
\text { Так само неможливо здійснити } \\
\text { об’єктивний аналіз і з боку лише } \\
\text { аудиторії. У кожної сторони є лише їй } \\
\text { притаманні критерії аналізу. Жоден із } \\
\text { критеріїв не відбиває об’єктивної картини } \\
\text { процесу й повинен розглядатися як }\end{array}$ \\
\hline
\end{tabular}


вільної частинки використовуються дві змінні: координата та імпульс, то у квантовій механіці існують два підходи: в одному змінною $\epsilon$ координата, а в іншому імпульс. Відповідно, в першому імпульс може мати точне значення, у другому точне значення може мати координата» (Принцип_доповнюваності, 2021; Кравченко, 2002; Давидов, 2012).

Підсумок

\begin{tabular}{|l|l|l|}
\hline 1 & $\begin{array}{l}\text { комплементарний один щодо одного. } \\
\text { Разом із тим один і той самий суб'єкт } \\
\text { (журналістський продукт) може мати як } \\
\text { оцінку його виробників, так й оцінку } \\
\text { об’єктів, на яких його спрямовано } \\
\text { (аудиторія). }\end{array}$ \\
\hline 100 & 0 & \\
\hline
\end{tabular}

По-третє, об'єкт і предмети журналістики не можна порівнювати 3 об'єктом і предметами вивчення у квантовій механіці, але в силу поширення понять, категорій i принципів останньої ми, як будь-який уважний інтуїтивний дослідник уловлюємо загальні філософські тенденції квантової механіки як складника наукової галузі «Фізика», так i журналістики, яка $є$ складником наукової галузі «Соціальні комунікації». Такі тенденції не лише зближують, на наш погляд, філософське розуміння процесів мікро- й макросвітів, але й підштовхують нас до розуміння фізики й соціальних комунікацій як системних частин знання Цілого, Сдиного, що часто називають Природою, Всесвітом, Абсолютом, Всевишнім, Богом, Аллахом, Буддою, Началом, Світобудовою тощо.

У дослідженні ми звертаємося до терміна «принципи методологічної інституалізації», який, на наш погляд, необхідно розтлумачити детально по відношенню до соціокультурного явища, що виникає в теорії соціальних комунікацій, - квантової журналістики.

Оскільки термін «інституалізація» $є$ похідним від терміна «інститут» («соціальний інститут»), варто уточнити значення останнього. Будемо спиратися на розуміння соціального інституту як «абстрактні - вигадані людьми обмеження, які визначають взаємодію людей. Ці обмеження дають інформацію про те, що заборонено в даній ситуації, а також які умови необхідно виконати, щоб мати можливість робити якісь дії, які права та обов'язки пов'язані 3 певними діями» (Клапків, 2015). На підставі такого тлумачення терміна «соціальний інститут» застосуємо його значення до процесу соціальних комунікацій, що містять поняття журналістики. Урахуємо, що журналістика $є$ видом соціальної фахової діяльності, спрямованої на збирання, відбір, формування, підготовку до трансляції та саму трансляцію інформації, а також подальшу орієнтацію на функції соціального інжинірингу й регуляцію соціальних відносин між соціальними групами, класами та інститутами. Якщо журналістику маємо право кваліфікувати як соціальний інститут, то квантову журналістику як складову журналістики також маємо називати соціальним інститутом, що дає нам поштовх до з'ясування значення поняття «інституалізація» та однойменного терміна, яким згадане поняття позначається в науковому обігу.

\section{Таблиця 3.}

Порівняльний аналіз класичних визначень принципів і понять квантової механіки та їхніх тлумачень у межах квантової журналістики (поняття «спостерігач» і «суперпозиція»)

\begin{tabular}{|c|c|c|}
\hline $\begin{array}{c}\text { Принципи й поняття } \\
\text { квантової } \\
\underline{\text { механіки }}\end{array}$ & $\begin{array}{c}\text { Ступінь } \\
\text { кореляції } \\
\text { (у \%): }\end{array}$ & $\begin{array}{c}\text { Принципи й поняття } \\
\text { квантової жсрналістики }\end{array}$ \\
\hline
\end{tabular}




\begin{tabular}{|c|c|c|c|}
\hline & 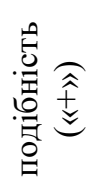 & 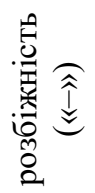 & \\
\hline \multicolumn{4}{|c|}{ Поняття «спостерігач» $\mathbf{i}$ «суперпозиція» } \\
\hline 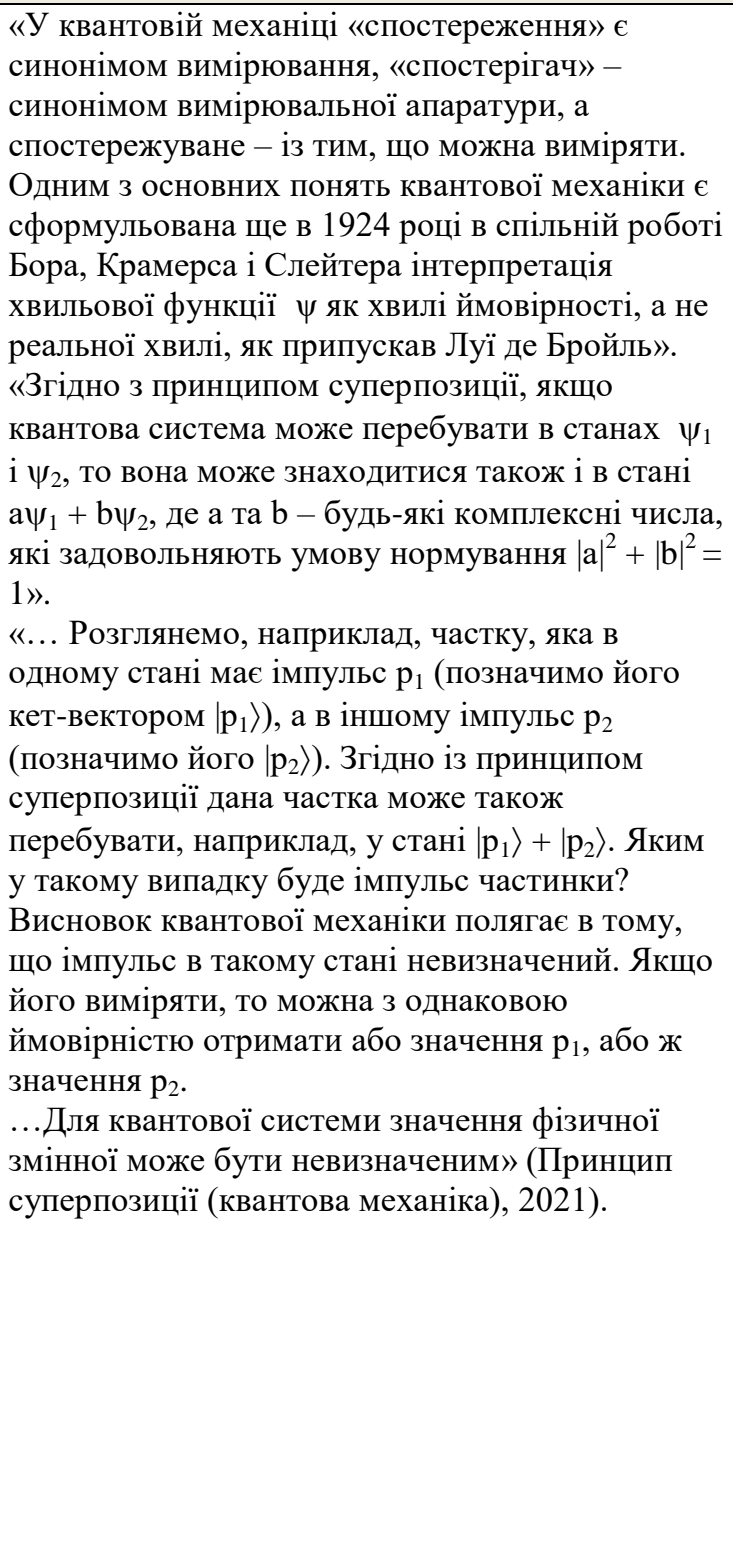 & + & - & $\begin{array}{l}\text { У квантовій журналістиці поняття } \\
\text { «суперпозиція» пов’язане з поняттям } \\
\text { «спостерігач» і застосовується до } \\
\text { інформації як порції енергії (кванту) у } \\
\text { декількох випадках: } \\
\text { 1) прояв кванту інформації можливий лише } \\
\text { тоді, коли є спостерігач (ним може бути } \\
\text { як сам журналіст, так й аудиторія, і } \\
\text { засоби вимірювання впливу мас-медіа на } \\
\text { аудиторію); без спостерігача інформація } \\
\text { не може колапсуватися (схлопуватися); } \\
\text { 2) коли журналіст, трансформуючи } \\
\text { інформацію згідно з поставленою метою, } \\
\text { може впливати на ії енергетичний } \\
\text { (квантовий) потенціал і формувати з неї } \\
\text { потрібний засіб маніпуляції (у формі } \\
\text { мутації, інмутації чи абмутації (Холод, } \\
\text { 2012); у такому випадку слід вважати, що } \\
\text { одна й та сама інформація має } \\
\text { можливість колапсуватися } \\
\text { (схлопуватися) різними журналістами по- } \\
\text { різному: іншими словами, саме журналіст } \\
\text { колапсує певний енергетичний } \\
\text { (квантовий) «заряд» інформації; причому } \\
\text { від рівня майстерності, типу } \\
\text { темпераменту, типу характеру, } \\
\text { інтелектуального фону й розумових } \\
\text { здібностей журналіста залежить ступінь } \\
\text { такої квантової зарядженості, як і ступінь } \\
\text { їі подальшої реалізації в суспільстві; } \\
\text { 3) коли здійснюється вимірювання } \\
\text { впливу квантової інформації на } \\
\text { аудиторію, непередбачуваною є реакція } \\
\text { аудиторії на вміст інформації: реакція } \\
\text { може бути як позитивна (мутаційна), так } \\
\text { негативна (інмутаційна), а іноді } \\
\text { абмутаційна реакція, коли може } \\
\text { фіксуватися відсутність будь-яких змін у } \\
\text { колективній поведінці аудиторії. }\end{array}$ \\
\hline Підсумок & 100 & 0 & \\
\hline
\end{tabular}

Звернімо увагу на те, що тлумачення терміна «інституалізація» різне в різних наукових школах і течіях. Разом із тим зустрічаємо визначення терміна «інституалізація» із досить близьким трактуванням. До таких визначень віднесемо, наприклад, дефініцію представників української (київської) соціологічної школи, які вважають, що інституалізацією є «процес організації та регулювання суспільного життя, благоустрою, формалізації та стандартизації суспільних відносин» (Поняття й ознаки соціального інституту, 2003). Автори статті про інституалізацію в енциклопедії «Britannica» також убачають у такому процесі «регулювання суспільної поведінки (тобто поведінки над індивідами) всередині організацій або цілих суспільств» (Institutionalization, 2021). Оскільки новий прошарок знань у межах соціальних 
комунікацій передбачає певний ступінь соціального регулювання в суспільстві, у подальшому дослідженні будемо послуговуватися саме останнім визначенням терміна «інституалізація».

Урахуємо також те, що як будь-який процес інституалізація складається 3 певних етапів. У межах американської соціологічної школи Корнельського університету дослідники називають чотири етапи інституалізації, а саме: інновацію, призвичаєння, об'єктивізацію й седиментацію (Tolbert \& Zucker, 2003). Автори енциклопедії «Britannica» пропонують розрізняти «щонайменше три дії: (1) вироблення правил або розстрочка, (2) адаптація правил або розробка найкращих практик, і (3) зміна правил або заміна старих правил новими» (Institutionalization, 2021). За своєю суттю обидві класифікації відбивають, на нашу думку, близькі специфічні риси, якими характеризуються відрізки, етапи, періоди процесу інституалізації. У подальшому дослідженні ми будемо послуговуватися положенням про трьохетапну структуру процесу інституалізації.

Нам необхідно застосувати згадане положення про етапність інституалізації, оскільки із цим пов'язаний процес її (інституалізації) появи, адаптації до нього (процесу) і заміна старих уявлень про журналістику на нову систему квантової журналістики. Тепер ми можемо перейти до визначення терміна «методологічна інституалізація», який, на наш погляд, можна тлумачити як процес регулювання складників соціального інституту завдяки конкретній методології (системі методів), законам і принципам, поняттям і категоріям, що пояснюють основи функціонування, дослідження й вивчення соціально значимих процесів.

Відштовхуючись від запропонованого визначення, можемо сформулювати дефініцію методологічної інституалізації квантової журналістики, яка полягає в декларації журналістики як фактору соціального регулювання й соціального інжинірингу, що здійснюються за допомогою системи принципів i категорій, запропонованих копенгагенською інтерпретацією квантової теорії. Нагадаємо, що поняття «копенгагенська інтерпретація квантової теорії» містить перелік тих понять і термінів, які ми уточнювали на початку дослідження, а саме:

1) принцип невизначеності В. Гейзенберга: «неможливо визначити значення всіх властивостей системи одночасно» (Копенгагенська інтерпретація, 2020);

2) принцип доповнюваності Н. Бора: «експериментально проявляється лише одна 3 дуальних властивостей квантової системи, а не обидві відразу» (Копенгагенська інтерпретація, 2020);

3) поняття «суперпозиції»: «квантова система може перебувати в стані, у якому вимірювання фізичної характеристики може давати різні результати, а хвильова функція лише визначає ймовірність того чи іншого результату» (Копенгагенська інтерпретація, 2020);

4) поняття «спостерігач»: «квантова система може бути повністю описана певним вектором стану, який визначає всі доступні спостерігачу знання про неї» (Копенгагенська інтерпретація, 2020);

5) корпускулярно-хвильовий дуалізм Луї де Бройля: «квантова система одночасно проявляє властивості, характерні для частинок і хвиль» (Копенгагенська інтерпретація, 2020);

6) когерентність вимірювання: під час вимірювання квантова система взаємодіє із класичним приладом; «під час вимірювання когерентність («властивість хвилі зберігати свої частотні, поляризаційні й фазові характеристики» (Когерентність, 2021)) квантового стану руйнується» (Копенгагенська інтерпретація, 2020);

7) принцип відповідності: «зі збільшенням розмірів квантової системи іiі властивості переходять у класичні» (Копенгагенська інтерпретація, 2020); 
8) опис квантової системи має ймовірнісний характер: «імовірність події задається квадратом норми вектору стану» (Копенгагенська інтерпретація, 2020) (вектор стану нами розглядається як «сукупність характеристик, що однозначно визначають стан квантової системи» (Вектор стану, 2021).

Звертаючи увагу на тлумачення понять і термінів квантової теорії, тепер ми маємо можливість сформулювати основні принципи методологічної інституалізації квантової журналістики.

1. Під час вивчення теоретичних основ квантової журналістики необхідно послуговуватися потенціалом квантової теорії (переважно іії копенгагенської інтерпретації).

2. Дослідження практичної діяльності в межах квантової журналістики необхідно здійснювати, спираючись на положення про те, що тенденції, які зафіксовано в царині мікросвіту, мають свої трансформації в макросвіті.

3. Теоретичне й практичне дослідження в межах квантової журналістики не можуть здійснюватися за допомогою лише матеріалістичного, ідеалістичного чи дуалістичного методологічного потенціалу. Валідною повинна бути методологія, що спирається на праксеологічний (практичний) характер здобутих верифікованих дослідницьких результатів.

4. Зазначена в п. 3 методологія не може обмежуватися лише гіпотетичними законами, принципами й аксіоматичними положеннями квантової теорії, оскільки головною спрямованістю квантової журналістики є активність людини в межах соціальних і духовних практик.

5. Квантову журналістику слід вважати соціальним інститутом.

6. Відповідно до п. 5 методологію квантової журналістики слід вважати інституалізованою, або такою, що пройшла етап інституалізації.

7. Оскільки сьогодні в науковому обігові відсутній термін, що позначав би соціальний інститут під назвою «квантова журналістика», відсутній понятійно-категорійний апарат, пов'язаний із тлумаченням основних термінів, положень, принципів і методів квантової журналістики, пропонуємо ввести в науковий обіг термін «квантова журналістика».

8. Оскільки міжнародною мовою науки є латина, пропонуємо такий переклад нового терміна «квантова журналістика» - quantum journalism.

9. Для спрощеного написання латиною запропонованого терміна «quantum journalism» пропонуємо створити складне слово «qjournal», яке $\epsilon$ літерно-морфемною абревіатурою, що утворилася шляхом від'єднання першої літери $\boldsymbol{q}$ від слова «quantum» і додавання до неї кореневої морфеми «journal-» від слова «journalism». Для спрощеного написання нового терміна пропонуємо вживати його скорочену форму «qjour», вимова якого латинською буде звучати як [k'udzour]. Оскільки від нового терміна «qjour» можливе утворення звукобуквеної (звуко-літерної) абревіатури, пропонуємо ще один варіант його написання - QJ iз вимовою [k'udzei]. Українською мовою запис новотвору буде мати такий вигляд - «кюжур» [k’udzour], або «кюджей» (із подальшим записом без лапок).

10. Кюджей $\epsilon$ теоретико-практичною формою суспільної діяльності фахівців із соціальних комунікацій.

11. Кюджей спирається на ідеї, що гіпотетично сформульовані в математиці й квантовій механіці.

12. У квантовій журналістиці одиницею аналізу (а також одиницею вимірювання) не $\epsilon$ сам текст (світлина, відео-, аудіоматеріал; гіпертекст) або його підготовка до сприйняття, не спосіб подавання (трансляція) або якість впливу змісту журналістського продукту на аудиторію, а є синергетично-конвергентна й крос-трансмедійна (у розумінні, яке пропонує О. Хворостина (Хворостина, 2016-1; Хворостина, 2016-2) єдність, елементи якої поодиниі 
(ізольовано) не можуть презентувати сукупну дію, з одного боку, $і$ які поодинці не репрезентують характеристик згаданої сукупності, з іншого боку.

\section{Висновки}

На початку дослідження нами була висунута гіпотеза про те, що квантова журналістика має основні принципи методологічної інституалізації. Запропонована гіпотеза була підтверджена.

Дійсно, до основних принципів методологічної інституалізації квантової журналістики слід віднести ті, що перераховано в п.п. 1-12.

\section{Перспективи подальшого дослідження}

Вважаємо доцільним зосередитися в майбутніх дослідженнях на таких проблемах:

1) пошук та ідентифікація валідних методів та методик вивчення процесів, що фіксуються у квантовій журналістиці;

2) визначення кількісних маркерів вимірювання ступенів фіксації й рівнів активності суб'єктів й об'єктів соціальних і духовних процесів, ідентифікованих у межах квантової журналістики;

3) пошук, ідентифікація й класифікація методик вимірювання ступенів фіксації й рівнів активності суб'єктів й об'єктів соціальних і духовних процесів, ідентифікованих у межах квантової журналістики;

4) визначення принципів і критеріїв здійснення повномасштабної багаторазової верифікації валідності залучених методів та методик дослідження процесів квантової журналістики.

\section{Література}

Вакарчук, І.О. (2012). Квантова механіка. Львів. 872.

Валідність. Енциклопедія сучасної України (2021). Дата звернення 15.01.2021 http://esu.com.ua/search_articles.php?id=32984

Вектор стану Дата звернення 17.01.2021 https://uk.wikipedia.org/wiki/Вектор_стану

Гейзенберг, В., Шрёдингер, Э., Дирак, П.А.М. (1934). Три нобелевских доклада. Москва Ленинград. 11-35.

Гейзенберг, В. Физика и философия. Часть и целое. Москва, 1989. 400 с. ISBN 5-02-012452-9. Давидов, О.С. (2012). Квантова механіка. Київ. 706.

Квант (2020). Дата звернення 29.12.2020 https://ru.wikipedia.org/Квант

$\begin{array}{llll}\text { Квантова механіка } & \text { (2020). } & \text { Дата } & 30.12 .2020\end{array}$ https://uk.wikipedia.org/wiki/Квантова_механіка

Клапків, Ю.М. (2015). Концептуалізації поняття інститут та інституалізація для ринку фінансових послуг. Вісник Асоиіації докторів філософії України. 01. Дата звернення 26.12.2020 http://aphd.ua/publication-32/

Когерентність. Дата звернення 29.12.2020: https://uk.wikipedia.org/wiki/Когерентність

Копенгагенська інтерпретація (2021). Дата звернення 26.01.2021 https://uk.wikipedia.org/wiki/Копенгагенська_інтерпретація

Кравченко, О. (2002). Доповняльності концепція. Філософський енцииклопедичний словник. B.I. Шинкарук (гол. редкол.). Київ. 742 с. ISBN 966-531-128-X.

Крутов, В.В. (2014). Возвращение к себе. Основы развития сознания и управления мышлением. Киев. 400. 
Крутов, В.В. (2019). Психолингвистический потенциал нейрогенеза (обоснование применения психолингвистических методик для самосовершенствования механизмов Сознания человека с использованием идеи нейрогенеза). Психолінгвістика. Вип. 25(1), 165-193. doi.org/10.31470/2309-1797-2019-25-1-165-193.

Крутов, В.В. (2020-1). Социально-коммуникационные практики по противодействию психическим травмам в парадигме «Сознание - Информация - Энергия - Материя». Сочіальні комунікації: теорія і практика. Том 10 (січень - червень). 139-155.

Крутов, В.В. (2020-2). Особенности квантовой модели взаимоотношения сознания и материи в работах Р. Пенроуза и С. Хамероффа. Соціальні комунікації: теорія і практика. Том 11 (липень - грудень). 11-25. DOI: 10.51423/2524-0471-2020-11-2-1.

Ландау, Л.Д., Лифшиц, Е.М. (2004). Квантовая механика (нерелятивистская теория). Москва, 2004. 800. ISBN 5-9221-0530-2.

Ландау, Л.Д., Лифшиц Е.М. (2008). Теоретическая физика. Москва, 2008. Т. 3. 800.

Научное знание. Проблема (2020). Дата звернення 26.12.2020 https:/ru.wikipedia.org/ /wiki/Научное_знание

Поняття й ознаки соціального інституту. Механізми здійснення інституціоналізації (2003). Соціологія. За ред. Н.П. Осипової. Київ. 67.

$\begin{array}{llll}\text { Принцип_доповнюваності (2021). } & \text { Дата } & \text { звернення } & \text { 201.2021 }\end{array}$ https://uk.wikipedia.org/wiki/Принцип_доповнюваності

Принцип суперпозиції (квантова механіка) (2021). Дата звернення 07.01.2021 https://uk.wikipedia.org/wiki/Принцип_суперпозиції_квантова_механіка

Хворостина, О.В. (2016-1). Трансмедіація контенту українських новинних ресурсів. Humanities and Social Sciences. IV (13), Issue 82. 50-53.

Хворостина, О.В. (2016-2). Явище трансмедіації контенту мережевих видань. Наукові записки Інституту журналістики, Т. 62. 33-41.

Холод, О.М. (2012). Інмутаційні, абмутаційні та мутаційні процеси сучасного суспільства в межах метатеорії маніпуляції. Світ соціальних комунікащій. Київ, Т. 8. 7-10.

Холод, О.М. (2020-1). Метод квантового хроноса в исследованиях отдалённой коммуникации (или анализ процессов дистанцированной коммуникации в пределах пространственновременного континуума). Соціальні комунікації: теорія і практика. Том 10 (січень червень). 32-67.

Холод, О.М. (2020-2). Передовицы советских газет 1941 года как семиотико-цветовой спектр с точки зрения квантовой теории (или Применение метода квантового хроноса в идентификации семиотических и колористических маркеров текстов газеты «Московский большевик» за 1941 год при их восприятии современными украинскими читателями 2020 года). Соціальні комунікаиії: теорія $і$ практика. Том 11 (липень грудень). 98-141. DOI: 10.51423/2524-0471-2020-11-2-8.

$\begin{array}{llll}\text { Эффект } & \text { наблюдателя } & \text { (2021). } & \text { Дата }\end{array}$ https://ru.wikipedia.org/wiki/Эффект_наблюдателя

$\begin{array}{lllll}\text { Institutionalization (2021). } & \text { Britannica. } & \text { Дата } & \text { звернення } & \text { 17.01.2021 }\end{array}$ https://www.britannica.com/topic/institutionalization

Schrödinger, E. (1935). Die gegenwärtige Situation in der Quantenmechanik. Naturwissenschaften. T. 23. 807-812.

Tolbert, P. S. \& Zucker, L. G. (1996). The institutionalization of institutional theory [Electronic version]. In S. Clegg, C. Hardy and W. Nord (Eds.), Handbook of organization studies. London: SAGE. 175-190. 


\section{Reference}

Vakarchuk, I.O. (2012). Kvantova mekhanika [Quantum mechanics]. Lviv. 872 [in Ukrainian].

Validnist. Entsyklopediia suchasnoi Ukrainy [Encyclopedia of Modern Ukraine] (2021). Data zvernennia 15.01.2021 http://esu.com.ua/search_articles.php?id=32984 [in Ukrainian].

Vektor stanu [State vector] (2021). Data zvernennia 17.01.2021: https://uk.wikipedia.org/wiki/Vektor_stanu [in Ukrainian].

Heizenberh, V., Shrëdynher, E., Dyrak, P. A. M. (1934). Try nobelevskykh doklada [Three Nobel Prizes]. Moscow - Lenynhrad. 11-35 [in Russian].

Heizenberh, V. Fyzyka y fylosofyia. Chast y tseloe [Physics and Philosophy. Part and whole]. Moscow, 1989. 400 s. ISBN 5-02-012452-9 [in Russian].

Davydov, O.S. (2012). Kvantova mekhanika [Quantum mechanics]. Kyiv. 706 [in Ukrainian].

Kvant [Quant] (2020). Data zvernennia 29.12.2020 https://ru.wikipedia.org/Kvant [in Russian].

Kvantova mekhanika [Quantum mechanics] (2020). Data zvernennia 30.12.2020 https://uk.wikipedia.org/wiki/Kvantova_mekhanika [in Ukrainian].

Klapkiv, Yu.M. (2015). Kontseptualizatsii poniattia instytut ta instytualizatsiia dlia rynku finansovykh posluh [Conceptualization of the concept of institution and institutionalization for the financial services market]. Visnyk Asotsiatsii doktoriv filosofii Ukrainy [Bulletin of the Association of Doctors of Ukraine]. 01. Data zvernennia 26.12.2020 http://aphd.ua/publication-32/ [in Ukrainian].

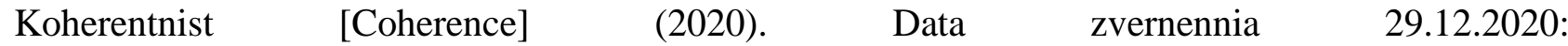
https://uk.wikipedia.org/wiki/Koherentnist [in Ukrainian].

Kopenhahenska interpretatsiia [Copenhagen interpretation] (2021). Data zvernennia 26.01.2021 https://uk.wikipedia.org/wiki/Kopenhahenska_interpretatsiia [in Ukrainian].

Kravchenko, O. (2002). Dopovnialnosti kontseptsiia [Complementarity concept]. Filosofskyi entsyklopedychnyi slovnyk [Philosophical Encyclopedic Dictionary]. V. I. Shynkaruk (hol. redkol.). Kyiv. 742 s. ISBN 966-531-128-X [in Ukrainian].

Krutov, V.V. (2014). Vozvrashchenye $k$ sebe. Osnovy razvytyia soznanyia y upravlenyia myshlenyem [Return to yourself. Fundamentals of Consciousness Development and Thinking Control]. Kyev. 400 [in Russian].

Krutov, V.V. (2019). Psykholynhvystycheskyi potentsyal neiroheneza (obosnovanye prymenenyia psykholynhvystycheskykh metodyk dlia samosovershenstvovanyia mekhanyzmov Soznanyia cheloveka s yspolzovanyem ydey neiroheneza) [Psycholinguistic potential of neurogenesis (substantiation of the application of techniques for self-improvement of the mechanisms of Human Consciousness using the ideas of neurogenesis)]. Psykholinhvistyka [Psycholinguistics]. Vyp. 25(1), 165-193. doi.org/10.31470/2309-1797-2019-25-1-165-193 [in Russian].

Krutov, V.V. (2020-1). Sotsyalno-kommunykatsyonnye praktyky po protyvodeistvyiu psykhycheskym travmam v paradyhme «Soznanye - Ynformatsyia - Enerhyia - Materyia» [Social and communication practices to counteract mental trauma in the paradigm «Consciousness - Information - Energy - Matter»]. Sotsialni komunikatsii: teoriia i praktyka [Social Communications: Theory and Practice]. Tom 10 (sichen - cherven). 139-155.

Krutov, V.V. (2020-2). Osobennosty kvantovoi modely vzaymootnoshenyia soznanyia y materyy v rabotakh R. Penrouza y S. Khameroffa [Features of the quantum model of the relationship between consciousness and matter in the works of R. Penrose and S. Hameroff]. Sotsialni komunikatsii: teoriia i praktyka [Social Communications: Theory and Practice]. Tom 11 (lypen - hruden). 11-25. DOI: 10.51423/2524-0471-2020-11-2-1 [in Russian]. 
Landau, L.D., Lyfshyts, E.M. (2004). Kvantovaia mekhanyka (nereliatyvystskaia teoryia) [Quantum mechanics (non-relativistic theory)]. Moscow, 2004. 800. ISBN 5-9221-0530-2 [in Russian].

Landau, L.D., Lyfshyts E.M. (2008). Teoretycheskaia fyzyka [Theoretical physics]. Moscow, 2008. T. 3. 800 [in Russian].

Nauchnoe znanye. Problema [Scientific knowledge. Problem] (2020). Data zvernennia 26.12.2020 https://ru.wikipedia.org//wiki/Nauchnoe_znanye [in Russian].

Poniattia y oznaky sotsialnoho instytutu. Mekhanizmy zdiisnennia instytutsionalizatsii [The concept and characteristics of a social institution. Mechanisms of institutionalization] (2003). Sotsiolohiia [Sociology]. Kyiv. 67 [in Ukrainian].

Pryntsyp_dopovniuvanosti [Principle_of_complementarity] (2021). Data zvernennia 07.01.2021 https://uk.wikipedia.org/wiki/Pryntsyp_dopovniuvanosti [in Ukrainian].

Pryntsyp superpozytsii (kvantova mekhanika) [Superposition principle (quantum mechanics)]. (2021). Data $\quad$ zvernennia 07.01 .2021 https://uk.wikipedia.org/wiki/Pryntsyp_superpozytsii_kvantova_mekhanika [in Ukrainian].

Khvorostyna, O.V. (2016-1). Transmediatsiia kontentu ukrainskykh novynnykh resursiv [Transmediation of content of Ukrainian news resources]. Humanities and Social Sciences. IV (13), Issue 82. 50-53 [in Ukrainian].

Khvorostyna, O.V. (2016-2). Yavyshche transmediatsii kontentu merezhevykh vydan [The phenomenon of content transmission of online publications]. Naukovi zapysky Instytutu zhurnalistyky [Scientific notes of the Institute of Journalism], T. 62. 33-41 [in Ukrainian].

Kholod, O.M. (2012). Inmutatsiini, abmutatsiini ta mutatsiini protsesy suchasnoho suspilstva $\mathrm{v}$ mezhakh metateorii manipuliatsii [Immutation, mutation and mutation processes of modern society within the metatheory of manipulation.]. Svit sotsialnykh komunikatsii [The world of social communications]. Kyiv, T. 8. 7-10 [in Ukrainian].

Kholod, O.M. (2020-1). Metod kvantovoho khronosa v yssledovanyiakh otdalonnoi kommunykatsyy (yly analyz protsessov dystantsyrovannoi kommunykatsyy $\mathrm{v}$ predelakh prostranstvenno-vremennoho kontynuuma) [The method of quantum chronos in studies of distant communication (or analysis of the processes of distant communication within the space-time continuum)]. Sotsialni komunikatsii: teoriia i praktyka [Social Communications: Theory and Practice]. Tom 10 (sichen - cherven). 32-67 [in Russian].

Kholod, O.M. (2020-2). Peredovytsy sovetskykh hazet 1941 hoda kak semyotyko-tsvetovoi spektr s tochky zrenyia kvantovoi teoryy (yly Prymenenye metoda kvantovoho khronosa v ydentyfykatsyy semyotycheskykh y kolorystycheskykh markerov tekstov hazety «Moskovskyi bolshevyk» za 1941 hod pry ykh vospryiatyy sovremennymy ukraynskymy chytateliamy 2020 hoda) [Editorials of Soviet newspapers in 1941 as a semiotic-color spectrum from the point of view of quantum theory (or Application of the quantum chronos method in identifying semiotic and coloristic markers of the texts of the Moscow Bolshevik newspaper for 1941 as perceived by modern Ukrainian readers in 2020)]. Sotsialni komunikatsii: teoriia i praktyka [Social Communications: Theory and Practice]. Tom 11 (lypen - hruden). 98-141. DOI: 10.51423/2524-0471-2020-11-2-8 [in Russian].

Effekt nabliudatelia [Observer effect]. (2021). Data zvernennia 09.01.2021 https://ru.wikipedia.org/wiki/Эffekt_nabliudatelia [in Russian].

$\begin{array}{lllll}\text { Institutionalization (2021). } & \text { Britannica. } & \text { Data } & \text { zvernennia } & \text { 17.01.2021 }\end{array}$ https://www.britannica.com/topic/institutionalization

Schrödinger, E. (1935). Die gegenwärtige Situation in der Quantenmechanik [The current situation in quantum mechanics]. Naturwissenschaften [Natural sciences]. T. 23. 807-812. 
Tolbert, P. S. \& Zucker, L. G. (1996). The institutionalization of institutional theory [Electronic version]. In S. Clegg, C. Hardy and W. Nord (Eds.), Handbook of organization studies. London: SAGE. 175-190.

\title{
КВАНТОВА ЖУРНАЛІСТИКА: ПРИНЦИПИ МЕТОДОЛОГІЧНОЇ ІНСТИТУАЛІЗАЦЇ
}

\author{
Олександр Холод, \\ доктор філологічних наук, завідувач кафедри журналістики \\ Прикарпатського національного університету імені Василя Стефаника
}

\section{Анотація}

У дослідженні ми поставили за мету сформулювати основні приниипи методологічної інституалізації квантової журналістики (лат. - «quantum journalism», скорочено - QJ із вимовою [k'udzei]; українською мовою - «кюджей»).

Методологія. У групі загальних методів був обраний метод моністичного ідеалізму, який передбачає первинність духу. У руслі моністичного ідеалізму спираємося на конщепцію квантової безмежності. Серед емпіричних методів послуговувалися аксіоматичним методом і гіпотетико-дедуктивним методом. Перший, аксіоматичний метод, дозволив висувати положення, щзо не вимагали доведення. На їхній базі виведено тези, щяо утворили аксіоматичну теорію про функиіонування квантової журналістики. Гіпотетикодедуктивний метод став основою для висування гіпотези й подальшого доведення ї̈ правильності иляхом дедукиії.

Висновки. За результатами дослідження були сформульовані основні принщипи методологічної інституалізаиії квантової журналістики. Під час вивчення теоретичних основ квантової журналістики необхідно послуговуватися потенціалом квантової теорії (переважно ї̈ копенгагенської інтерпретачіï). Дослідження практичної діяльності в межах квантової журналістики необхідно здійснювати, спираючись на положення про те, щзо тендениії, які зафіксовано в иарині мікросвіту, мають свої трансформації в макросвіті. Квантову журналістику слід вважати соціальним інститутом, яка $\epsilon$ теоретикопрактичною формою суспільної діяльності фахівців із соціальних комунікацій $і$ спирається на ідеї, шоо гіпотетично сформульовані в математиці й квантовій механіці. У квантовій журналістиці одиницею аналізу (а також одиницею вимірювання) $\epsilon$ синергетичноконвергентна й крос-трансмедійна єдність, елементи якої поодинці (ізольовано) не можуть презентувати сукупну дію, з одного боку, $і$ які поодиниі не репрезентують характеристик згаданої сукупності, з іншого боку.

Ключові слова: квантова журналістика, методологічна інституалізація, квантова механіка, інституалізація.

Submitted to the editor - 12.02.2021

Reviewed-06.04.2021

Accepted for printing - 01.07.2021

Подано до редакиії - 12.02.2021

Рецензовано - 06.04.2021

Прийнято до друку -01.07.2021 
Kholod, O. (2021). Quantum Journalism: Principles of Methodological Institutionalization.

Social Communications: Theory and Practice, Vol. 12(1), 22-37.

DOI: 10.51423/2524-0471-2021-12-1-1

p 